\title{
Ethnological inquiry into sexual behaviours at risk to homosexuals in Portugal
}

\author{
Marta Maia ${ }^{{ }^{*}}$, Khalid Fekhari ${ }^{2}$ \\ From $16^{\text {th }}$ International Symposium on HIV and Emerging Infectious Diseases \\ Marseille, France. 24-26 March 2010
}

\section{Background}

In Portugal, since 1982 homosexuality is not any more a crime. However, the population remains profoundly homophobe. Marriage isn't allowed between persons of the same sex and crimes or attacks against homosexuals, transsexual or transgender punctuate actuality. The condition of oppressed minority predominates in their group identity but also in their own identity, in their self-definition. As a result, these practices are considered twice more transgressive. The socially transgressive context in which take place these sexual exchanges sets the individuals in a territory considered "out of limits".

\section{Methods}

As part of a research on sexual behaviours in the Portuguese population led by the Institute of Social sciences of the University of Lisbon, I realized ten interviews with both homosexual and bisexual men, from 20 to 65 years, in the areas of Lisbon and Porto.

\section{Results}

The most part of the interviewed is having sexual relations with occasional partners, notably in meeting places and saunas. The questioned persons define these relations as sexual exchanges dominated by the only and simple quest of pleasure, anonymity and freedom. These moments, governed by transgression, are lived as parentheses in daily life. In this special context, knowing that prevention takes more the path of duty (having to protect oneself and having to protect partners) than free choice, desire and pleasure, men are breaking occasionally the safer sex rules.

\section{Discussion}

Without forgetting that the difficulty in maintaining long-term prevention sexual behaviours, the increase of the longevity of the hiv positive and regarding trivialization of illness led by HAART, all aspects have to be considered to explain the relapse (the slackening of precautionary behaviours), the question of transgression of the actors and their practices must be added to the dynamics of risky behaviours.

Author details

${ }^{1}$ CRIA - ISCTE, Lisbon, Portugal. ${ }^{2}$ Instituto Piaget, Viseu, Portugal.

Published: 11 May 2010

doi:10.1186/1742-4690-7-S1-P121

Cite this article as: Maia and Fekhari: Ethnological inquiry into sexual behaviours at risk to homosexuals in Portugal. Retrovirology 2010 7(Suppl 1):P121.

\footnotetext{
* Correspondence: martamaia72@yahoo.fr
}

${ }^{1}$ CRIA - ISCTE, Lisbon, Portugal

Submit your next manuscript to BioMed Central and take full advantage of:

- Convenient online submission

- Thorough peer review

- No space constraints or color figure charges

- Immediate publication on acceptance

- Inclusion in PubMed, CAS, Scopus and Google Scholar

- Research which is freely available for redistribution

Submit your manuscript at www.biomedcentral.com/submit
C Biomed Central 